\section{Evaluation of carcass hygiene in sheep subjected to gas de-pelting with different skinning procedures}

\author{
David Ranucci, ${ }^{1}$ Raffaella Branciari, ${ }^{1}$ \\ Dino Miraglia, ${ }^{1}$ Roberta Stocchi, ${ }^{2}$ \\ Stefano Rea, ${ }^{2}$ Anna Rita Loschi ${ }^{2}$ \\ 'Dipartimento di Medicina Veterinaria, \\ Università degli Studi di Perugia; ${ }^{2}$ Scuola \\ di Bioscienze e Medicina Veterinaria, \\ Università degli Studi di Camerino, \\ Matelica (MC), Italy
}

\section{Abstract}

The aim of the study was to evaluate the hygienic status of sheep carcasses skinned with two different procedures, the pulling down and $Y$ cut methods, with and without the use of compressed filtered air inflation. Five sheep carcasses per day for each of the four skinning methods considered were sampled on ten different slaughtering days using wet and dry swab techniques at a local abattoir specialised in ovine slaughtering. A pool of four different sampling sites (brisket, shoulder, thorax and rump) was considered for each animal. Furthermore, ten animals were also randomly selected on different slaughtering days for each of the four skinning techniques and the four sampling sites were separately swabbed and analysed in each animal. The total viable count (TVC) and Enterobacteriaceae count were performed and the presence of Salmonella spp. was also tested. The daily average mean value of each parameter was in compliance with limits set by Regulation (EC) 1441/2007, falling into satisfactory or acceptable category for Enterobacteriaceae and within the acceptable level range for TVC for both the methods used with and without air de-pelting. For both TVC and Enterobacteriaceae count, no statistically significant differences $(\mathrm{P}>0.05)$ were recorded between samples obtained from carcasses skinned with and without air inflation for either of the skinning methods used and any of the sites sampled. No Salmonella spp. were detected in any of the tested samples. Nonetheless, no improvement in the carcass hygiene was detected either and, for this reason, other aspects should be taken into consideration when considering adopting the gas de-pelting method.

\section{Introduction}

The carcass surface is unavoidably contaminated during the slaughtering of meat produc- ing animals. Operators' hands and knives that are not sterile come into contact with the carcass and transfer bacteria to its surface, during bleeding, pelting, evisceration (Hadley et al., 1997) and post-mortem inspection (Walker et al., 2000). The most frequently involved step among the above mentioned procedures is skinning, especially of unsheared sheep and lambs, when bacteria present in the hide can spread to the carcass not only by cross-contamination but also by direct contact of the carcass surface with the fleece (Biss and Hathaway, 1996). Reducing the possibility of surface contamination is very important and, for this reason, an appropriate de-pelting method is crucial to assure the hygienic status of the carcasses. A number of methods that facilitate the skinning process while ensuring carcass hygiene have been reported (European Commission, 2001b), among which de-pelting using inflation of filtered compressed air is found. Air inflation is a method commonly used in Italy (Severini, 1996) allowed by EC Directive 95/23 (European Commission, 1995) only for skinning of lamb of live weight under $15 \mathrm{~kg}$, when the hygienic conditions of the procedures are checked and approved by the official veterinary inspector. In Regulation (EC) 853/2004 (European Commission, 2004) the use of air inflation is not mentioned anymore. Few data about differences in the hygienic status of carcasses de-pelted with and without air inflation, mainly for lambs, are present in the literature (Trevisani et al., 1996; Severini et al., 2000). The aim of this work is to evaluate the hygienic condition of adult ovine carcasses (of live weight over $15 \mathrm{~kg}$ ) skinned using two different methods with and without the use of filtered compressed air. A comparison between the data obtained and the process hygiene criteria set by Commission Regulation 1441/2007 (European Commission, 2007) is also drawn.

\section{Materials and Methods}

The study was conducted in two separate steps. In the first step the hygienic status of carcasses skinned with two different dressing procedures, the pulling down and $Y$ cut methods (Table 1; Figure 1) with and without the use of compressed filtered air inflation [exercise pressure $900 \mathrm{kPa}$ for $10-15 \mathrm{sec} ; 0.01 \mathrm{~m}$ aseptic filter mod.; Ethafilter s.r.l., Sovizzo (VI), Italy], was determined. Air was inflated from the forelegs before or after the removal of the front hooves. On ten different days, five sheep carcasses per day for each of the four skinning methods were sampled at a local abattoir specialised in ovine slaughtering. A pool of four different sampling sites (brisket, shoulder, thorax and rump) was considered for each animal. Wet and dry swab techniques, as
Correspondence: David Ranucci, Dipartimento di Medicina Veterinaria, Università degli Studi di Perugia, via San Costanzo 4, 06126 Perugia, Italy. Tel. +39.075.5857931 - Fax: +39.075.5857928.

E-mail: david.ranucci@unipg.it

Key words: Sheep, Carcass hygiene, Gas de-pelting, Slaughtering.

Conflict of interests: the authors declare no potential conflict of interests.

Acknowledgments: this paper is in memory of Prof. Maurizio Severini, ten years after his passing away.

Received for publication: 21 May 2014.

Revision received: 27 June 2014.

Accepted for publication: 27 June 2014.

This work is licensed under a Creative Commons Attribution 3.0 License (by-nc 3.0).

(C) Copyright D. Ranucci et al., 2014

Licensee PAGEPress, Italy

Italian Journal of Food Safety 2014; 3:4143

doi:10.4081/ijfs.2014.4143

described in standard ISO 17604 (ISO, 2014), were used over a $100 \mathrm{~cm}^{2}$ area delimited by a sterile template for each sampling site (total area sampled of $400 \mathrm{~cm}^{2}$ ) and swabs obtained for each carcass were collected in a single vial containing $10 \mathrm{~mL}$ of maxim recovery diluent (MRD; Oxoid Ltd., Basingstoke, UK). Samples were transported at refrigeration temperature to the laboratory and immediately analysed. Serial dilutions in MRD were obtained. On them, total viable count (TVC) using Plate Count Agar (Oxoid Ltd.) aerobically incubated at $30^{\circ} \mathrm{C}$ for $72 \mathrm{~h}$, and Enterobacteriaceae count using Violet Red Bile Glucose Agar (VRBG; Oxoid Ltd.) aerobically incubated at $30^{\circ} \mathrm{C}$ for $24 \mathrm{~h}$, were determined. The results were normalised to colony forming unit (CFU)/ $\mathrm{cm}^{2}$ and converted into $\log _{10}$ values. The means of the log values were then calculated for each sampling day for each skinning method. The presence of Salmonella spp. was determined following UNI EN ISO 6579:2008 (UNI, 2008).

The second step aimed at determining whether the use of air inflation could change surface contamination on one of the sampling sites considered. For this reason, 10 animals were randomly selected on 5 different slaughtering days for each of the four skinning techniques. In each animal the four sampling sites were separately swabbed with the above mentioned method and separately analysed. Total viable count, Enterobacteriaceae count and Salmonella spp. were determined as previously described. The results were normalised to $\mathrm{CFU} / \mathrm{cm}^{2}$ and converted into $\log _{10}$ values. Mean values and standard deviations were calculated 
for TVC and Enterobacteriaceae count. For the latter, when bacteria were not detected at the level of $1.0 \mathrm{CFU} / \mathrm{cm}^{2}$, a value of $-0.5 \log _{10}$ $\mathrm{CFU} / \mathrm{cm}^{2}$ was assigned (Byrne et al., 2007). The effect of skinning with the aid of compressed filtered air was evaluated for pulling down and $Y$ cut methods separately using the unpaired T test (Statview; SAS Inst. Inc., Cary, NC, USA) and the significance level was set at a value of $\mathrm{P}<0.05$.

\section{Results}

Enterobacteraceae were detected in 60 and $50 \%$ of the samples for the pulling down method assisted with and without filtered compressed air, respectively, and for both $Y$ cut methods in $70 \%$ of the samples (data not shown). The results of the first step of the trial are reported in Table 1, while those of the second step are reported in Tables 2 and 3 for TVC and Enterobacteriaceae, respectively. For both TVC and Enterobacteriaceae count, no statisti-
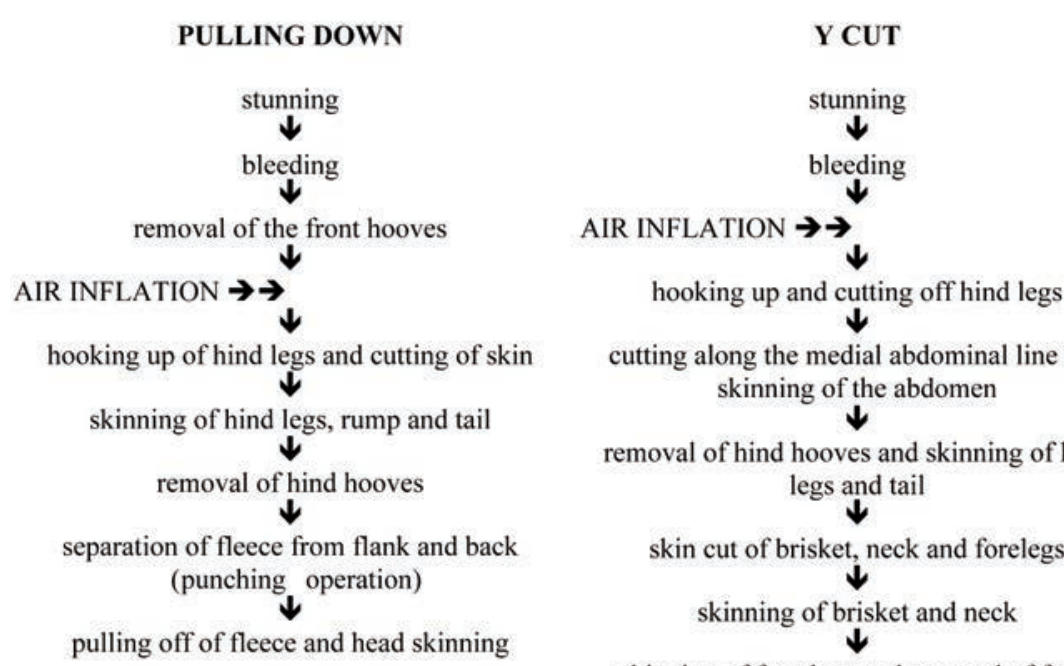

cutting along the medial abdominal line and skinning of the abdomen

removal of hind hooves and skinning of hind legs and tail

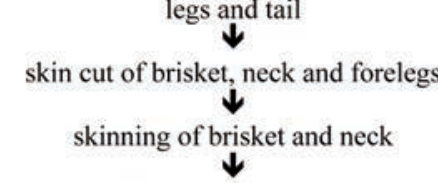

skinning of frontlegs and removal of front hooves

pulling off of skin and head skinning

Figure 1. Flowchart of the skinning methods used in the present study.

Table 1. Total viable and Enterobacteriaceae counts obtained from sheep carcasses skinned by pulling down and $Y$ cut methods with and without use of filtered air inflation: first step of trial.

\begin{tabular}{|c|c|c|c|c|c|c|}
\hline Parameter & Skinni & thod & Samples (n) & $\begin{array}{c}\text { Mean value } \\
\left(\log _{10} \text { CFU/cm²) }\right.\end{array}$ & SD & P* \\
\hline TVC & $\begin{array}{c}\text { Pulling down } \\
\text { Ycut }\end{array}$ & $\begin{array}{l}\text { With air } \\
\text { Without air } \\
\text { With air } \\
\text { Without air }\end{array}$ & $\begin{array}{l}50 \\
50 \\
50 \\
50\end{array}$ & $\begin{array}{l}3.25 \\
3.38 \\
3.47 \\
3.31\end{array}$ & $\begin{array}{l}0.58 \\
0.55 \\
0.35 \\
0.26\end{array}$ & 0.635 \\
\hline Enterobacteriaceae & $\begin{array}{c}\text { Pulling down } \\
\text { Ycut }\end{array}$ & $\begin{array}{l}\text { With air } \\
\text { Without air } \\
\text { With air } \\
\text { Without air }\end{array}$ & $\begin{array}{l}50 \\
50 \\
50 \\
50\end{array}$ & $\begin{array}{l}0.62 \\
0.36 \\
0.75 \\
0.68\end{array}$ & $\begin{array}{l}1.10 \\
1.02 \\
1.05 \\
1.09\end{array}$ & 0.587 \\
\hline
\end{tabular}

SD, standard deviation; CFU, colony forming unit; TVC, total viable count. *Not significant at $\mathrm{P}>0.05$.

Table 2. Total viable count obtained from different sampling sites of sheep carcasses skinned by pulling down and $Y$ cut methods with and without use of filtered air inflation: second step of trial.

\begin{tabular}{|c|c|c|c|c|c|c|}
\hline Sampling site & Skinni & ethod & Samples (n) & $\begin{array}{c}\text { Mean value } \\
\left(\log _{10} \mathrm{CFU} / \mathrm{cm}^{2}\right)\end{array}$ & SD & P* \\
\hline Rump & $\begin{array}{c}\text { Pulling down } \\
\text { Ycut }\end{array}$ & $\begin{array}{l}\text { With air } \\
\text { Without air } \\
\text { With air } \\
\text { Without air }\end{array}$ & $\begin{array}{l}10 \\
10 \\
10 \\
10\end{array}$ & $\begin{array}{l}3.23 \\
3.51 \\
3.47 \\
3.39\end{array}$ & $\begin{array}{l}0.47 \\
0.63 \\
0.45 \\
0.83\end{array}$ & $\begin{array}{l}0.279 \\
0.817\end{array}$ \\
\hline Thorax & $\begin{array}{l}\text { Pulling down } \\
\text { Ycut }\end{array}$ & $\begin{array}{l}\text { With air } \\
\text { Without air } \\
\text { With air } \\
\text { Without air }\end{array}$ & $\begin{array}{l}10 \\
10 \\
10 \\
10\end{array}$ & $\begin{array}{l}3.04 \\
3.07 \\
3.21 \\
3.16\end{array}$ & $\begin{array}{l}0.56 \\
0.62 \\
0.43 \\
0.50\end{array}$ & $\begin{array}{l}0.923 \\
0.809\end{array}$ \\
\hline Brisket & $\begin{array}{c}\text { Pulling down } \\
\text { Ycut }\end{array}$ & $\begin{array}{l}\text { With air } \\
\text { Without air } \\
\text { With air } \\
\text { Without air }\end{array}$ & $\begin{array}{l}10 \\
10 \\
10 \\
10\end{array}$ & $\begin{array}{l}3.11 \\
3.42 \\
2.92 \\
3.17\end{array}$ & $\begin{array}{l}0.45 \\
0.75 \\
0.64 \\
0.87\end{array}$ & $\begin{array}{l}0.277 \\
0.474\end{array}$ \\
\hline Shoulder & $\begin{array}{l}\text { Pulling down } \\
\text { Ycut }\end{array}$ & $\begin{array}{l}\text { With air } \\
\text { Without air } \\
\text { With air } \\
\text { Without air }\end{array}$ & $\begin{array}{l}10 \\
10 \\
10 \\
10\end{array}$ & $\begin{array}{l}3.01 \\
2.81 \\
3.46 \\
3.32\end{array}$ & $\begin{array}{l}0.70 \\
0.64 \\
0.95 \\
0.75\end{array}$ & $\begin{array}{l}0.516 \\
0.710\end{array}$ \\
\hline
\end{tabular}

SD, standard deviation. *Not significant at $\mathrm{P}>0.05$. 
Table 3. Enterobacteriaceae count obtained from different sampling sites of sheep carcasses skinned by pulling down and $Y$ cut methods with and without use of filtered air inflation: second step of trial.

\begin{tabular}{|c|c|c|c|c|c|c|}
\hline Sampling site & Skinni & thod & Samples (n) & $\begin{array}{c}\text { Mean value } \\
\left(\log _{10} \text { CFU/cm²) }\right.\end{array}$ & SD & P* \\
\hline Rump & $\begin{array}{l}\text { Pulling down } \\
\qquad Y \text { cut }\end{array}$ & $\begin{array}{l}\text { With air } \\
\text { Without air } \\
\text { With air } \\
\text { Without air }\end{array}$ & $\begin{array}{l}10 \\
10 \\
10 \\
10\end{array}$ & $\begin{array}{l}0.66 \\
0.98 \\
1.24 \\
1.27\end{array}$ & $\begin{array}{l}1.32 \\
1.37 \\
1.28 \\
1.20\end{array}$ & $\begin{array}{l}0.595 \\
0.371\end{array}$ \\
\hline Thorax & $\begin{array}{l}\text { Pulling down } \\
\qquad Y \text { cut }\end{array}$ & $\begin{array}{l}\text { With air } \\
\text { Without air } \\
\text { With air } \\
\text { Without air }\end{array}$ & $\begin{array}{l}10 \\
10 \\
10 \\
10\end{array}$ & $\begin{array}{l}-0.32 \\
-0.23 \\
-0.30 \\
-0,19\end{array}$ & $\begin{array}{l}0.39 \\
0.44 \\
0.44 \\
0.67\end{array}$ & $\begin{array}{l}0.642 \\
0.682\end{array}$ \\
\hline Brisket & $\begin{array}{l}\text { Pulling down } \\
\qquad \text { Ycut }\end{array}$ & $\begin{array}{l}\text { With air } \\
\text { Without air } \\
\text { With air } \\
\text { Without air }\end{array}$ & $\begin{array}{l}10 \\
10 \\
10 \\
10\end{array}$ & $\begin{array}{c}-0.30 \\
0.04 \\
-0.02 \\
-0.01\end{array}$ & $\begin{array}{l}0.43 \\
0.73 \\
0.80 \\
0.84\end{array}$ & $\begin{array}{l}0.218 \\
0.970\end{array}$ \\
\hline Shoulder & $\begin{array}{l}\text { Pulling down } \\
\qquad Y \text { cut }\end{array}$ & $\begin{array}{l}\text { With air } \\
\text { Without air } \\
\text { With air } \\
\text { Without air }\end{array}$ & $\begin{array}{l}10 \\
10 \\
10 \\
10\end{array}$ & $\begin{array}{c}0.01 \\
0,13 \\
0.01 \\
-0,21\end{array}$ & $\begin{array}{l}0.85 \\
0.84 \\
0.79 \\
0,61\end{array}$ & $\begin{array}{l}0.734 \\
0.337\end{array}$ \\
\hline
\end{tabular}

SD, standard deviation. *Not significant at $\mathrm{P}>0.05$.

cally significant differences were recorded between samples obtained from carcasses skinned with and without air for either of the skinning methods used and any of the sites sampled. No Salmonella spp. were detected in any of the tested samples.

\section{Discussion}

The results obtained in the first step of the study showed values in compliance with limits set by Regulation (EC) 1441/2007 (European Commission, 2007) for carcasses sampled using non-destructive method. In this case the Italian legislation reports that the limits set by Regulation (EC) 1441/2007 have to be reduced to $1 / 5$ (Italian Republic, 2007), as suggested by Commission Decision 471/2001 (European Commission, 2001a) which indicates that the swab sampling removes only a part (often $20 \%$ or less) of the total flora present on the meat surface $\left(\mathrm{m}=2.80 \log _{10} \mathrm{CFU} / \mathrm{cm}^{2}\right.$ and $\mathrm{M}=4.30$ $\log _{10} \mathrm{CFU} / \mathrm{cm}^{2}$ for TVC; $\mathrm{m}=0.80 \log _{10} \mathrm{CFU} / \mathrm{cm}^{2}$ and $\quad \mathrm{M}=1.80 \quad \log _{10} \quad \mathrm{CFU} / \mathrm{cm}^{2} \quad$ for Enterobacteriaceae). For both parameters the results fell into the satisfactory or acceptable category for Enterobacteriaceae and within the acceptable level range for both of the skinning methods with and without air de-pelting.

The TVCs were similar to those reported in the literature on ovine carcasses, even though using different slaughtering and sampling procedures (Sumner et al., 2003; Byrne et al., 2007; Nouichi and Hamdi, 2009; Phillips et al., 2013), or even lower than data reported by other authors (Milios et al., 2011). The same was observed as for the Enterobacteriaceae count (Lenahan et al., 2010). The use of air inflation in both of the skinning techniques did not affect the hygienic status of sheep carcasses, as previously reported for lambs (Severini et al., 2000). This result was evident both for the daily average hygienic level and for the different sampling areas, thus proving that air inflation procedure does not affect the hygiene of the carcass surface. No improvement in the hygienic condition of the carcasses was detected and, for this reason, other aspects should be taken into consideration in choosing the use of gas de-pelting in ovine, such as the time necessary for pelt removal, the appearance of the carcass surface or the reduction of skin damage (Severini et al., 1994). No considerations could be made for Salmonella spp. since all the samples were negative, as other authors also reported (Lenahan et al., 2010).

The use of gas de-pelting is allowed in other countries (New Zealand), where compressed filtered air can be used. Those who choose to use this method for industrial production must have an approved Hazard Analysis and Critical Control Points (HACCP) plan with microbiological monitoring for its validation (Ministry of Agriculture and Forestry of New Zealand, 2002). The present study gives further evidence that this could be a reliable method to use in Europe too, as almost all the checked lots of production obtained with air inflation satisfied the hygiene parameters set by legislation. Nonetheless, the official veterinary inspector could request further investigation on the hygiene level of the procedure when unacceptable levels of carcass surface contamination are detected and the food business operators could implement specific prerequisite programme of the HACCP system adopted. The use of air inflation could also be evaluated for other dressing systems, such as the inverted one (Bell and Lovatt, 1999).

\section{Conclusions}

The use of air inflation to assist ovine skinning did not increase surface contamination in adult ovine carcasses in either of the manual skinning methods used. However, the use of air inflation, in combination with mechanisation, as well as the cleaning level of the fleece in live animals transported to the slaughterhouse, still need further consideration and studies.

\section{References}

Bell RG, Lovatt SJ, 1999. A hygiene perspective of gas injection as a ovine carcass dressing aid. Document prepared for MAF regulatory authority, New Zealand. Ministry of Agriculture and Forestry of New Zealand ed., Wellington, New Zealand.

Biss ME, Hathaway SC, 1996. Microbial contamination of ovine carcass associated with the presence of wool and fecal material. J Appl Bacteriol 81:594-600.

Byrne B, Dunne G, Lyng J, Bolton DJ, 2007. The development of a "clean sheep policy" in compliance with the new Hygiene Regulation (EC) 853/2004 (Hygiene 2). Food Microbiol 24:301-4.

European Commission, 1995. Council Directive 95/23/EC of 22 June 1995 amending Directive 64/433/EEC on conditions for the production and marketing of fresh 
meat. In: Official Journal, L 143, 11-101995.

European Commission, 2001a. Commission Decision of 8 June 2001 laying down rules for the regular checks on the general hygiene carried out by the operators in establishments according to Directive 64/433/EEC on health conditions for the production and marketing of fresh meat and Directive 71/118/EEC on health problems affecting the production and placing on the market of fresh poultry meat, 2001/471/EC. In: Official Journal, L 165/48, 21-06-2001.

European Commission, 2001b. Opinion of the scientific committee on measures relating to veterinary public health on ovine gas de-pelting. Adopted on 14-15 February 2001. European Commission ed., Brussels, Belgium. Available from: http://ec.europa. eu/food/fs/sc/scv/outcome_en.html

European Commission, 2004. Regulation of the European Parliament and of the council of 29 April 2004 laying down specific hygiene rules for on the hygiene of foodstuffs, 853/2004/EC. In: Official Journal, L 139, 30-04-2004.

European Commission, 2007. Regulation of 5 December 2007 amending Regulation (EC) No 2073/2005 on microbiological criteria for foodstuffs, 1441/2007/EC. In: Official Journal, L 322, 7-12-2007.

Hadley PJ, Holder JS, Hinton MH, 1997. Effects of the fleece soiling and skinning method on the microbiology of sheep carcass. Vet Rec 140:570-4.

ISO, 2014. Microbiology of the food chain. Carcass sampling for microbiological analysis. ISO/DIS Norm 17604. International
Standardization Organization ed., Geneva, Switzerland.

Italian Republic, 2007. [Determinazione Conferenza Stato, Regioni, Province Autonome del 10 maggio 2007. Intesa, ai sensi dell'articolo 8, comma 6, della legge 5 giugno 2003, n. 131, tra il Governo, le Regioni e le Province autonome di Trento e di Bolzano su "Linee guida relative all'applicazione del Regolamento CE della Commissione europea n. 2073 del 15 novembre 2005 che stabilisce i criteri microbiologici applicabili ai prodotti alimentari". Repertorio Atti n. 93/CSR.]. [Regulation in Italian]. In: Official Journal, L 124, 30-05-2007, Ordinary Suppl. $n^{\circ} 126$.

Lenahan M, 0’Brian SB, Kinsella K, Sweeney T, Sheridan JJ, 2010. Assessment of lamb carcass hygiene before and after chilling at five Irish abattoirs. Food Control 21:3138.

Milios K, Mataragas M, Pantouvakis A, Drosin EH, Zoiopoulos PE, 2011. Evaluation of control over the microbiological contamination of carcass in lamb carcass dressing process operated with or without pasteurizing treatment. Int $\mathrm{J}$ Food Microbiol 146:170-5.

Ministry of Agriculture and Forestry of New Zealand, 2002. Industrial standard 5: slaughtering and dressing. Available from: www.foodsafety.govt.nz/industry/sectors/m eat-ostrich-emu-game/meatman/is5/

Nouichi S, Hamdi TM, 2009. Superficial bacterial contamination of ovine and bovine carcasses at El-Harrach slaughterhouse (Algeria). Eur J Sci Res 38:474-85.

Phillips D, Tholath S, Jenson I, Sumner J,
2013. Microbiological quality of Australian sheep meat in 2011. Food Control 31:291-4.

Severini M, 1996. Assisting pelt removal by air inflation. Meat Int 6:39-41.

Severini M, Ranucci D, Cenci Goga BT, Miraglia D, 2000. Microbiological aspects of ovine pelt removal assisted by air inflation. In: Proc. $46^{\text {th }}$ Int. Congr. on Meat Science and Technology, 27 August-1 September 2000, Buenos Aires, Argentina. Elsevier Applied Science, Oxford, UK, pp 680-1.

Severini M, Trevisani M, Loschi AR, 1994. Pelt removal in lambs: the issue of air inflation. Meat Focus Int 3:446-51.

Sumner J, Petrenas E, Dean P, Dowsett P, West G, Wiering R, Raven G, 2003. Microbial contamination of beef and sheep carcases in South Australia. Int $\mathrm{J}$ Food Microbiol 81:255-300.

Trevisani M, Cenci Goga BT, Loschi A, Severini M, 1996. The effect of depelting with air inflation on the appearence and microbiology of lamb carcasses. In: Proc. $42^{\text {nd }}$ Int. Congr. on Meat Science and Technology, 16 September 1996, Lillehammer, Norway. Elsevier Applied Science, Oxford, UK, pp 450-1.

UNI, 2008. UNI EN ISO Norm 6579:2008. [Microbiologia di alimenti e mangimi per animali. Metodo orizzontale per la ricerca di Salmonella spp.]. [Regulation in Italian]. Italian Unification Institute ed., Milan, Italy.

Walker HL, Chowdhury KA, Thaler AM, Petersen KE, Ragland RD, James WO, 2000. Relevance of carcass palpation in lambs to protecting public health. J Food Protect 9:1287-90. 